\title{
"A Comparative Study of Management of Anemia in Pregnancy by Oral and Parenteral Therapy"
}

Dr. Homaira Shahreen (Simi) ${ }^{*}$

*Corresponding author: Dr. Homaira Shahreen (Simi)

Abstract

Introduction: Iron deficiency anemia is a common problem presented in antenatal patients throughout the developing countries across the world. Its prevalence is estimated to be from $20-80 \%$ worldwide with a greater percentage in the third world countries. The higher prevalence of anemia in pregnancy is a cause of concern as it causes considerable morbidity and mortality. The problem of Iron deficiency is more severe in the poor rural and tribal pregnant female population of our country. Aims: We in the present study tried to evaluate the results of treatment of iron deficiency anemia in pregnant females with oral and parenteral iron supplements and evaluate the effects of the treatment on the hemoglobin and iron status. Methods: This prospective cross-sectional study was conducted in the Department of Obstetrics and Gynecology, Rajshahi Medical College Hospital, Rajshahi, Bangladesh for a period of 6 months (January to Jun-2019). The patients were randomly selected from those visiting the OPD of the Department of Obstetrics and Gynecology for ANC. A total of $n=78$ patients with anemia were included in the study. The patients were evaluated completely including a complete history, clinical examinations and laboratory investigations were ordered with a complete hematological profile including serum iron, serum folate levels, urine, and stool examination. After obtaining the results the patients were separated into three groups Group I, II, \& III (mild, moderate and severe) anemia. The mild and moderate groups were given only oral iron supplementation for 2 months and severe anemia was treated with IV iron sucrose for 1 to 2 weeks followed by oral supplementation. Results: The mean age was 24.5 years. The mean $\mathrm{Hb}$ levels in Group I was $8.2 \pm 2.6 \mathrm{gm} / \mathrm{dl}$ and in group II the mean Hb levels were $7.5 \pm 1.9 \mathrm{gm} / \mathrm{dl}$ and in group III the levels were $6.5 \pm 1.1 \mathrm{gm} / \mathrm{dl}$. In the group I the mean Hb levels increased at 8 weeks to $10.4 \mathrm{gm} / \mathrm{dl}$. The serum iron pretreatment was $80 \mu \mathrm{gm} / \mathrm{dl}$ and increased up to $90.5 \mu \mathrm{gm} / \mathrm{dl}$ at 4 weeks and $100.2 @ 8$ weeks interval. In group II at 8 weeks the mean $\mathrm{Hb}$ levels were increased to $9.9 \mathrm{gm} / \mathrm{dl}$. The serum iron pretreatment was $77 \mu \mathrm{gm} / \mathrm{dl}$ and increased up to $98.5 \mu \mathrm{gm} / \mathrm{dl}$ at 4 weeks and 105.5 @ 8 weeks interval. In the group III the mean Hb levels were increased to $8.1 \mathrm{gm} / \mathrm{dl}$ at the end of 4 weeks and $10.1 \mathrm{gm} / \mathrm{dl}$ at the end of 8 weeks. The serum iron levels pretreatment values were $62 \mu \mathrm{gm} / \mathrm{dl}$ and increased to $99.0 \mu \mathrm{gm} / \mathrm{dl}$ at the end of 4 weeks and $106.4 \mu \mathrm{gm} / \mathrm{dl}$ at the end of 8 weeks. Conclusion: it can be concluded that Iron deficiency anemia is common in this group of pregnant females and the response of parenterally administered iron was better as compared to the oral administration of iron supplements and therefore parenteral administration of iron should be done whenever it is indicated without hesitation.

Keywords: Iron Deficiency Anemia, Oral Iron Supplements, Parenteral Iron Supplements.

Copyright $\odot 2020$ The Author(s): This is an open-access article distributed under the terms of the Creative Commons Attribution 4.0 International License (CC BY-NC 4.0) which permits unrestricted use, distribution, and reproduction in any medium for non-commercial use provided the original author and source are credited.

\section{INTRODUCTION}

Iron deficiency anemia is a common problem presented in antenatal patients throughout the developing countries across the world. Its prevalence is estimated to be from $20-80 \%$ worldwide with a greater percentage in the third world countries [1, 2]. The higher prevalence of anemia in pregnancy is a cause of concern as it causes considerable morbidity and mortality [3]. The WHO defined anemia as a state where hemoglobin concentration in less than $11 \mathrm{gm} / \mathrm{dl}$ and Hct $<33 \%$ [4]. The important causes of iron deficiency anemia are poor nutrition, malaria, hookworm infestations and lack of adequate space between successive pregnancies. The results of anemia in pregnancy are increased in the number of preterm deliveries, lower birth weight, impaired cognitive development of children, and postpartum hemorrhage [5]. Therefore laboratory testing of all the pregnant ladies for maternal iron deficiency anemia is essential [6]. Adequate supplementation of iron either orally or parenterally is an important method of management in cases of anemia in pregnant women [7]. The evidence has shown that long term oral iron supplementation has shown partial success with issues relating the compliance and other factors. Therefore parenteral iron 
therapy is used and advocated with an idea to replenish iron stores more efficiently, completely and faster and oral iron therapy [8]. Iron sucrose is currently being utilized for a parenteral form of iron therapy in place of previously used iron dextran the IV infusion of sucrose has shown remarkable success without the issues of adverse effects. With this background we in the present study tried to evaluate the outcomes of iron deficiency anemia in our tertiary care hospital which caters to a large population of tribal and poor people and the prevalence of iron deficiency is very common here in pregnant females and such a study will provide important aspects regarding the treatment of Iron deficiency in this group of population.

\section{AIM OF THE STUDY}

We in the present study tried to evaluate the results of treatment of iron deficiency anemia in pregnant females with oral and parenteral iron supplements and evaluate the effects of the treatment on the hemoglobin and iron status.

\section{Materials ANd Methods}

This prospective cross-sectional study was conducted in the Department of Obstetrics and Gynecology, Rajshahi Medical College Hospital, Rajshahi, Bangladesh for a period of 6 months (January to Jun-2019). Institutional Ethical committee permission was obtained for the study. Written consent was obtained from all the patients involved in the study after explaining the nature of the study in their local language. The patients were randomly selected from those visiting the OPD of the Department of Obstetrics and Gynecology for ANC. The inclusion criteria were all the pregnant females with suspected anemia. Excluded patients were females with other comorbidities and complications. The selected patients were evaluated completely including a complete history, clinical examinations and laboratory investigations were ordered with a complete hematological profile including serum iron, serum folate levels, urine, and stool examination. After obtaining the results the patients were separated into three groups Group I $(n=24)$ were the patients with mild anemia the $\mathrm{Hb}$ levels were between 8-9 gm/dl and without any complications. They were given Tab Ferrous Sulphate $300 \mathrm{mg}$ /day and tablet folic acid $500 \square$ gm once daily for 2 months. Group II $(\mathrm{n}=30)$ patients were classified as moderately anemic and having average $\mathrm{Hb}$ levels between 7.0 to $8.0 \mathrm{gm} / \mathrm{dl}$. They were also given Tab Ferrous Sulphate $300 \mathrm{mg} /$ day and tablet folic acid 500 $\square$ gm once daily for 2 months. Group III was $(n=24)$ having severe anemia the average $\mathrm{Hb}$ levels were between 6.0 to $7.0 \mathrm{gm} / \mathrm{dl}$. They were first administered $1 \mathrm{ml}$ of Iron Sucrose was as a test dose followed by a window period of 15 minutes and when no adverse reactions were seen IV Iron Sucrose was administered as $200 \mathrm{mg}$ of elemental iron in $100 \mathrm{ml}$ of $0.9 \%$ normal saline over one hour every alternate day. Total dose to calculate the iron requirement of the patient was used as-[TDI (Total dose infusion) $=\mathrm{Wt}$. (kg.) $\times(120 \mathrm{~g} / \mathrm{L}-$ Actual Hemoglobin $\mathrm{g} / \mathrm{L}) \times 0.24+500 \mathrm{mg}]$ this treatment was done for 1-2 weeks followed by Tab Ferrous Sulphate $300 \mathrm{mg} /$ day and tablet folic acid $500 \square \mathrm{gm}$ once daily for 2 months. The data of the patients were recorded before and after the therapy and it was tabulated and analyzed for the changes before and after the therapy.

\section{RESULTS}

A total of $n=78$ patients with anemia were included in the study. The age range was from 19-40 years. The mean age was 24.5 years out of the patients $\mathrm{n}=27(34.62 \%)$ were between age group 21-25 years followed by $n=17(21.79 \%)$ were between the age group $26-30$ years, similarly $n=15(19.23 \%)$ patients were between $19-20$ years and $n=11(14.10 \%$ were $31-35$ years and $n=8(10.26 \%)$ were between $36-40$ years shown in (table 1).

Table-1: Distribution of the patients involved in the study ( $N=78$ )

\begin{tabular}{|l|c|c|c|c|l|}
\hline \multirow{2}{*}{$\begin{array}{l}\text { Age } \\
\text { Group }\end{array}$} & \multicolumn{3}{|c|}{ Antenatal (weeks) } & No of cases & Percentage \\
\cline { 2 - 4 } & $\mathbf{1 6} \mathbf{- 2 0}$ & $\mathbf{2 1} \mathbf{- 2 4}$ & $\mathbf{2 5} \mathbf{- 2 8}$ & & \\
\hline $19-20$ & 6 & 7 & 2 & 15 & 19.23 \\
\hline $21-25$ & 11 & 10 & 6 & 27 & 34.62 \\
\hline $26-30$ & 7 & 6 & 4 & 17 & 21.79 \\
\hline $31-35$ & 4 & 4 & 3 & 11 & 14.10 \\
\hline $36-40$ & 3 & 2 & 3 & 08 & 10.26 \\
\hline Total & 31 & 29 & 18 & 78 & 100 \\
\hline
\end{tabular}

The Hematological profiles of the patients were recorded before the beginning of therapy. The mean $\mathrm{Hb}$ levels in Group I was $8.2 \pm 2.6 \mathrm{gm} / \mathrm{dl}$ and in group II the mean $\mathrm{Hb}$ levels were $7.5 \pm 1.9 \mathrm{gm} / \mathrm{dl}$ and ingroup III the levels were $6.5 \pm 1.1 \mathrm{gm} / \mathrm{dl}$. Similarly, the RBC counts in millions/mm3 and reticulocyte count (\%) are given in the (table 2). 
Table-2: Hematological parameters before the therapy $(\mathrm{N}=78)$

\begin{tabular}{|l|c|c|c|c|c|c|}
\hline & \multicolumn{2}{|c|}{ Hemoglobin in gm/dl } & \multicolumn{2}{c|}{ RBC count in million/mm } & \multicolumn{2}{c|}{ Reticulocyte Count (\%) } \\
\cline { 2 - 7 } & Mean & Range & Mean & Range & Mean & Range \\
\hline Group I & $8.2 \pm 2.6$ & $7.1-9.1$ & $3.7 \pm 1.1$ & $3.0-4.5$ & $0.5 \pm 0.1$ & $0.3-1.1$ \\
\hline Group II & $7.5 \pm 1.9$ & $7.0-8.0$ & $3.1 \pm 0.9$ & $2.9-4.1$ & $0.55 \pm 0.1$ & $0.35-1.8$ \\
\hline Group III & $6.5 \pm 1.1$ & $5.5-7.0$ & $2.9 \pm 0.6$ & $2.5-3.8$ & $0.6 \pm 0.2$ & $0.5-2.1$ \\
\hline
\end{tabular}

Table-3: Showing the serum Iron and folate levels before the therapy $(\mathrm{N}=78)$

\begin{tabular}{|l|c|c|c|c|}
\hline & \multicolumn{2}{|c|}{ Serum Iron $\boldsymbol{\mu g m} / \mathbf{d l}$} & \multicolumn{2}{c|}{ Serum Folate $\mathbf{~ n g} / \mathbf{m l}$} \\
\cline { 2 - 5 } & Mean \pm Sd & Range & Mean \pm Sd & Range \\
\hline Group I & $80 \pm 10.5$ & $55.5-110$ & $8.1 \pm 2.3$ & $6-12$ \\
\hline Group II & $77 \pm 11.2$ & $49.5-95$ & $7.4 \pm 1.5$ & $4.5-11.5$ \\
\hline Group III & $62 \pm 9.4$ & $41.5-90$ & $6.5 \pm 1.8$ & $4.2-8.9$ \\
\hline
\end{tabular}

The mean serum iron levels before the therapy in the group I was between $55.5-110 \square \mathrm{g} / \mathrm{dl}$ and the mean values were $80 \pm 10.5 \square \mathrm{g} / \mathrm{dl}$. In group II the range of serum Irons was between 49.5-95 $\square \mathrm{g} / \mathrm{dl}$ mean levels were $77 \pm 11.2 \square \mathrm{g} / \mathrm{dl}$. In group III the mean levels were
$62 \pm 9.4 \square \mathrm{g} / \mathrm{dl}$ and the range was $41.5-90 \square \mathrm{g} / \mathrm{dl}$. Similarly, the mean serum folate levels in $\mathrm{ng} / \mathrm{ml}$ in Group I, II and III were $8.1 \pm 2.3,7.4 \pm 1.5$, and 6.5 $\pm 1.8 \mathrm{ng} / \mathrm{ml}$ respectively (table 3 ).

Table-4: Hematological changes after the therapy $(N=78)$

\begin{tabular}{|l|l|c|c|c|c|c|c|}
\hline \multirow{2}{*}{ Parameter } & & \multicolumn{2}{|c|}{ Group I } & \multicolumn{2}{c|}{ Group II } & \multicolumn{2}{c|}{ Group III } \\
\cline { 3 - 8 } & & 4 weeks & 8 weeks & 4 weeks & 8 weeks & 4 weeks & 8 weeks \\
\hline \multirow{2}{*}{$\begin{array}{l}\text { Hemoglobin in } \\
\text { gm/dl }\end{array}$} & Mean & 9.6 & 10.4 & 8.6 & 9.9 & 8.1 & 10.1 \\
\cline { 2 - 8 } & Range & $8.1-10.1$ & $9.5-10.8$ & $7.6-9.2$ & $8.2-10.1$ & 7.59 .5 & $8.8-10.6$ \\
\hline \multirow{2}{*}{$\begin{array}{l}\text { Serum Iron in } \\
\mu \mathrm{gm} / \mathrm{dl}\end{array}$} & Mean & 90.5 & 100.2 & 98.5 & 105.5 & 99.0 & 106.4 \\
\cline { 2 - 8 } & Range & $80.6-95.5$ & $90.1-105.8$ & $85.5-100$ & $98.8-110.0$ & $86-101.5$ & $100-110.5$ \\
\hline $\begin{array}{l}\text { Serum Folate } \\
\text { in } \mathrm{ng} / \mathrm{ml}\end{array}$ & Mean & 9.0 & 9.5 & 8.1 & 9.1 & 7.5 & 9.0 \\
\cline { 2 - 8 } & Range & $7.5-9.5$ & $8.3-10.1$ & $7.9-9.3$ & $8.2-9.6$ & $8.0-8.9$ & $7.8-10.1$ \\
\hline
\end{tabular}

The hematological changes observed after the treatment were recorded in each group at the end of 4 weeks and 8 weeks. In the group I at the end of 4 weeks the mean $\mathrm{Hb}$ levels increased from the pretreatment mean value of $8.2 \mathrm{gm} / \mathrm{dl}$ to $9.6 \mathrm{gm} / \mathrm{dl}$ and levels were further increased at 8 weeks to $10.4 \mathrm{gm} / \mathrm{dl}$. The serum iron pretreatment was $80 \mu \mathrm{gm} / \mathrm{dl}$ and increased up to $90.5 \mu \mathrm{gm} / \mathrm{dl}$ at 4 weeks and $100.2 @ 8$ weeks interval. Similarly, the serum folate levels in group I pretreatment were $8.1 \mathrm{ng} / \mathrm{ml}$ increased to 9.0 at 4 weeks and $9.5 \mathrm{ng} / \mathrm{ml}$ at the end of 8 weeks. In the group II at the end of 4 weeks, the mean Hb levels increased from the pre-treatment mean value of $7.5 \mathrm{gm} / \mathrm{dl}$ to $8.6 \mathrm{gm} / \mathrm{dl}$ and levels were further increased at 8 weeks to $9.9 \mathrm{gm} / \mathrm{dl}$.
The serum iron pretreatment was $77 \mu \mathrm{gm} / \mathrm{dl}$ and increased up to $98.5 \mu \mathrm{gm} / \mathrm{dl}$ at 4 weeks and $105.5 @ 8$ weeks interval. The serum folate levels in group I pretreatment was $7.4 \mathrm{ng} / \mathrm{ml}$ increased to 8.1 at 4 weeks and $9.1 \mathrm{ng} / \mathrm{ml}$ at the end of 8 weeks. In the group, III the mean pretreatment levels of $\mathrm{Hb}$ were $6.5 \mathrm{gm} / \mathrm{dl}$ were increased to $8.1 \mathrm{gm} / \mathrm{dl}$ at the end of 4 weeks and 10.1 $\mathrm{gm} / \mathrm{dl}$ at the end of 8 weeks. The serum iron levels pretreatment values were $62 \mu \mathrm{gm} / \mathrm{dl}$ and increased to $99.0 \mu \mathrm{gm} / \mathrm{dl}$ at the end of 4 weeks and $106.4 \mu \mathrm{gm} / \mathrm{dl}$ at the end of 8 weeks the serum folate levels pretreatment were $6.5 \mathrm{ng} / \mathrm{ml}$ and increased to $7.5 \mathrm{ng} / \mathrm{ml}$ at 4 weeks and further increased to $9.0 \mathrm{ng} / \mathrm{ml}$ at the end of 8 weeks shown in (table 4).

Table-5: complication reported for oral/parenteral Iron therapy $(\mathrm{N}=78)$

\begin{tabular}{|l|c|c|c|c|}
\hline Complication & Group I & Group II & Group III & Total \\
\hline Diarrhea & 04 & 02 & 01 & 07 \\
\hline Vomiting & 01 & 01 & 04 & 06 \\
\hline Constipation & 00 & 00 & 00 & 01 \\
\hline Stomach upset & 01 & 01 & 00 & 01 \\
\hline Total & 06 & 04 & 05 & 15 \\
\hline
\end{tabular}

The frequencies of complications were also recorded during the study. The most common complication in Group I and Group II who were given oral iron reported diarrhea $\mathrm{n}=6$ and vomiting andstomach upset in Two cases each. In the parenteral
Group III, there were $n=4$ cases of vomiting and one case of diarrhea. All the complications were minor and they have been managed adequately (table 5). 


\section{DISCUSSION}

Nutritional deficiency anemias are a very common problem in developing countries like Bangladesh the frequency is especially higher in females of poor rural and tribal areas. Hence, we decided to conduct this type of study to find the actual scenario in pregnant tribal females. The majority of pregnant females suffer iron deficiency had it leads to several consequences for the mother and fetus [9]. Since an iron deficiency in pregnancy leads to adverse effects on the development of the fetus and therefore routine iron supplementation during pregnancy should be given. In the present study, we gave parenteral Iron Sucrose IV for 2 weeks in cases of severe anemia and posttreatment response of the patients with severe anemia was better as compared to the other two groups of mild and moderate anemia respectively. This can be explained in two ways the first one it appears the when the iron is given parenteral route it bypasses the GI effects of inhibitors of Iron absorption and secondly the iron binding capacity transport, and utilization mechanisms become more efficient. A study by Francoise B et al. [10] gave iron sucrose IV weekly found better iron levels in patients receiving the IV iron sucrose. Whereas Al-Memon et al. [11], reported no significant differences in the effectiveness of oral iron from parenteral iron on an elevation of $\mathrm{Hb}$ concentrations in pregnancy. It has been recognized that oral iron therapy may not be sufficient for pregnant women with severe iron deficiency because of increased demand of iron and patients who respond to oral treatment often require months to reach the normal levels of hemoglobin [12]. It has been estimated that a pregnant woman without anemia require $1000 \mathrm{mg}$ of elemental iron to delivered to hemopoietic organs while anemic one requires > $2600 \mathrm{mg}$. Unlubilgin et al. comparing the efficacy of IV iron to the oral iron treatment of anemia in pregnancy found that IV iron treated deficiency faster and restored the iron stores faster as compared to the oral routes [13]. The main reason for doctors to avoid parenteral iron therapy was due to the concerns of toxic allergic and even anaphylactic reactions in dextran preparations. However, the current type II $\mathrm{Fe}$ (iron sucrose) that releases iron the iron binding proteins with $t 1 / 26$ hours are very effective and has only minimal risks of allergic accidents and iron overload [14]. The problem of poor compliance faced by the doctors is reduced in parenteral forms of administrations and therefore treating doctors must not hesitate to use parenteral forms of iron if required. In the present study, the overall incidences of complications were minimal and mild nature those were adequately managed and no case of serious side effects due to treatment were noted in the study.

\section{Conclusion}

Within the limitations of the present study, it can be concluded that Iron deficiency anemia is common in this group of pregnant females and the response of parenterally administered iron was better as compared to the oral administration of iron supplements and therefore parenteral administration of iron should be done whenever it is indicated without hesitation.

\section{REFERENCES}

1. Breymann C. Iron deficiency anemia in pregnancy. Semin Hematol. 2015; 52(4):339-47.

2. Lawrence $P$ McMahon. Iron deficiency in pregnancy. Obstet Med. 2010; 3(1):17-24.

3. Cutner A. Failed response to treat anemia in pregnancy reasons \& evaluation. J Obstet Gynecol. 1999; (Suppl): 523-27.

4. World Health Organization Nutritional anemia: tools for effective prevention and control. 2017; 183.[ https://www.who.int/nutrition/publications/mic ronutrients/anaemias-tools-prevention-control/en/ Accessed on Jan 15, 2019].

5. Scholl TO. Iron status during pregnancy: setting the stage for mother and infant. The American journal of clinical nutrition. 2005 May 1; 81(5):1218S-22S. 6.

6. Mukherji J, Ganguly RP, Saha SK, Ray SCH. Postpartum care: a neglected tragedy. J Obstet Gynecol India. 2002; 52(4):40-3.

7. Indian Council of Medical Research Supplementation trial in pregnant women with $60 \mathrm{mg}$, $120 \mathrm{mg}$ and $180 \mathrm{mg}$ Iron with 500 of folic acid, New Delhi, ICMR. 1992:641.

8. Schultink W. Iron supplementation program: Compliance of target groups and frequency of tablet intake. Food Nutr Bull. 1996; 17:22-6.

9. McMullin MF, White R, Lappin T, Reeves J, and Mackenzie G. Haemoglobin during pregnancy: relationship to erythropoietin and haematinic status. Eur J Haematol. 2003; 71:44-50.

10. Françoise B, Carole SB, Nour-Eddine B, Henryse L, Patricia MB, Marie CL. Iron therapy in iron deficiency anemia in pregnancy: Intravenous route versus oral route, Am J Obstet Gynecol. 2002;186:518-22.

11. Al-Memon, Almeshari, Al, Saddique N, Abotalib A Khashogu Z. Intravenous iron sucrose complex in the treatment of iron deficiency and anemia in pregnancy Eur J Obstet-Gynecol Reprod Bio. 1996; 69:121-24.

12. Monika Dalal, Rita Ranjan, Sunita Seth, Comparison of Oral and Intravenous Iron for Treatment of Iron Deficiency Anaemia in Pregnancy. Indian Medical Gazette Sept. 2012; 372-375.

13. Al RA, Unlubilgin E, Kandemir O, Yalvac S, Cakir L, Haberal A. Intravenous versus oral iron for treatment of anemia in pregnancy: a randomized trial. Obstetrics \& Gynecology. 2005 Dec $1 ; 106(6): 1335-40$.

Perewusnyk G, Huch R, Huch A, Breymann C. Parenteral iron therapy in obstetrics: 8 years' experience with iron-sucrose complex. $\mathrm{Br} \mathbf{J}$ Nutr. 2002; 88: 3-10. 